\title{
Developing Humanistic Leadership Education
}

\author{
Sandra Waddock ${ }^{1}$
}

Received: 21 October 2015 / Accepted: 5 January 2016 / Published online: 28 July 2016

(C) Springer International Publishing 2016

\begin{abstract}
In this paper, I will argue, supported by interviews with a number of leading academics, that perhaps the MBA program, which is unlikely to change to meet numerous critiques, should be left as is with acknowledgement that its purpose is education that provides analytical, functional, and technical skills, and, basically, the first couple of positions out of business school. With that core acknowledgement, business schools could then also develop more humanistic approaches to leading and managing for individuals who have progressed in their work to the types of positions where humanistic capabilities associated with wisdom-moral imagination, systems understanding, and aesthetic sensibility in the service of the greater good-are vitally important and can better be learned. Through interviews with leading academics, I outline core elements of a wisdom-based approach to leadership development over time.
\end{abstract}

Keywords Humanistic leadership · MBA education · Management education · Leadership education $\cdot$ Wisdom

The Humanistic Management Network, a group of scholars oriented towards influencing management education, practicing managers, policy makers in a wide range of capacities and levels, and public opinion has set forth a vision:

Our vision is a global economy that protects human dignity and promotes human wellbeing in an economic system in which all stakeholders are equally respected so that market mechanisms are applied to maximize societal benefits rather than individual profits; an economy in which economic rationality is applied as a means rather than an end in itself. (www.humannetwork. org/index.php/en/about-us/mission-vision)

Sandra Waddock waddock@bc.edu 
Toward that end, the Humanistic Management Network has created a short 'manifesto' on its website, which argues that 'market economies hold a substantial potential for human development,' but that their activities need to be life-conducive, encompass respect for human dignity and freedom, collective decision-making within companies as well as governments. The orientation is towards collaboration and cooperation and the treatment of people as ends rather than as means towards some economic or market-based end. Fundamentally, the Humanistic Management Network questions current management education, particularly as manifested in MBA programs' tendency to educate for technical and analytic skills rather than for leading and managing (e.g., Mintzberg 2004).

In this paper, I will argue, supported by interviews with a number of leading academics listed above who spoke generally about management education, that perhaps the MBA program, which is unlikely to change, should be left as is. Not trying to change the MBA means acknowledging that its purpose, as actually manifested in practice, is education for analytical, functional, and technical skills, and, basically, the knowledge that relatively inexperienced and low level managers and analysts need. With that core acknowledgement, business schools could then also develop more humanistic approaches to leading for individuals who have progressed in their work to positions where leading demands people and social skills, i.e., humanistic capabilities associated with wisdom, defined as moral imagination, systems understanding, and aesthetic sensibility in the service of the greater good (Waddock 2010).

The Humanistic Management Network argues that much of that education today is deeply imbued with a model of managing economic institutions and businesses far from respecting human dignity, the worth of the natural environment, or human wellbeing. Yet there are farsighted management scholars who believe that management education can and should be reoriented towards a more humanistic leadership model. In what follows, I will first briefly provide some background on the current state of management education and scholarship, then focus on the ways in which these leading management scholars, who were interviewed for my book Intellectual Shamans (Waddock et al. 2015), believe that leadership education might be transformed towards a more humanistic model.

A humanistic approach to leading focused on mid-to-late career leaders versus novices, will be framed through the lens of wisdom, The idea is that humanistic management education fundamentally demands that the future leaders need to be something more than the technicians and analysts as they contend with internal and external stakeholders and business and other enterprise in a fraught and complex world. In this context, leaders have a responsibility to act with wisdom, where wisdom is defined as follows:

- Wisdom is the integration of:

- Moral imagination or the ability to see the ethical issues and consequences in a situation (Werhane 1999, 2002, 2008), that is, 'the good';

- Systems understanding or a reasonably realistic and holistic perspective on the situation (Senge 1990; Werhane 2002), or 'the true'; and

- Aesthetic sensibility or the ability to see and assess the design and aesthetic issues and consequences in a situation 
- In the service of the greater good (Waddock 2010, 2014).

The numerous critiques of management education and scholarship, only a few of which can be highlighted below, suggest that educating for wisdom and humanism is currently far from the thoughts of most management academics.

\section{Background}

By many accounts, management education is in trouble and has been for a while (e.g., Pfeffer and Fong 2002; Mintzberg 2004; Bennis and O’Toole 2005; Ghoshal 2005; Giacalone 2007; Datar et al. 2010; Khurana 2010, and the list could go on). Unfortunately, these troubles are not new, though some problems seem to have gotten more egregious. For example, Hayes and Abernathy (1980), citing the 'paralysis of analysis,' claimed as long ago as 1980 that management education was a major factor in what they perceived as economic decline. Cheit (1985, p. 50-51) documents a long history of criticism of business schools, grouping the critiques into four categories: emphasizing the wrong model (e.g., a technical and analytic orientation rather than leading and managing); ignoring important work, especially related to human interactions; failing to meet society's needs; and fostering undesirable attitudes. None of these critiques seem to have abated much in the ensuing decades, as numerous studies emphasize that graduates of business schools seem to lack needed 'soft' or interpersonal skills, among other criticisms (Porter and McKibbin 1988; Shipper 1999; Datar et al. 2010).

It is not that solutions to issues associated with management education have not been suggested (e.g., Giacalone 2004; Mintzberg 2004; Giacalone and Thompson 2006; Adler and Harzing 2009; Khurana 2010; Porter and McKibbin 1988; Datar et al. 2010; Waddock and Lozano 2013, among many others). It is simply that today institutional inertia, rankings, and related numbers that are easily gathered, take precedence in evaluating many MBA programs, though they may have little relevance to anything useful or humanistic in the actual educational process. In far too many instances, management educators seem have been patently unable (or unwilling) to shift programs deal with, or even understand, the real problems of the world so that they can assume leadership for $21^{\text {st }}$ century organizations and issues (e.g., $50+20$ 2012). Instead of teaching about managerial issues, MBA programs teach functional, technical, and analytical skills that, while useful in first jobs, insufficiently prepare graduates for the real issues of leading in a world fraught with problems (e.g., Mintzberg 2004). That seems unlikely to change, so why not accept MBA programs for what they actually do-and devise new humanistic leadership programs for more career-advanced leaders, managers, and entrepreneur where wisdom and humanistic skills are clearly needed?

Many business schools claim that they are developing leaders, but their real focus on the quantitative analysis, functional, and technical skills belies that assertion. Most MBA graduates can solve well-defined problems, but at core they are unprepared for leading (Mintzberg 2004) and may be indoctrinated with ideas that cause more harm than good (Ghoshal 2005). The University of Michigan's Robert E. (Bob) Quinn articulates one reason: 'Let me see if I can capture this in a nutshell. You walk through the foyer of the business school, and you look at these young people, heavily steeped in statistics and marketing [and other] technical, logical, problem-solving stuff. What that means is they're perfectly qualified to be managers. Managers solve problems 12 hours a day [and] keep the [existing] system in equilibrium. 
Managers preserve value. ... [But] our language around the business school is "We're teaching leadership." They are hopelessly disqualified for that, because leadership is not about problemsolving. It's about purpose finding. It's about making a mess of and distorting the order that exists and bringing about a new order.'

Henry Mintzberg of McGill University minces few words in discussing his even harsher assessment of the state of management education, 'The first thing I would do is stamp every graduate of an MBA program with a skull and crossbones that reads, "Not prepared to manage." I wouldn't close down MBA programs, but I would make it absolutely clear that they're being trained as analysts, not managers. They're not prepared to manage and moreover, to the extent that these programs give the impression that the graduates are prepared to manage, they're dysfunctional. Destructive is better than dysfunctional. They're destructive.'

There's more. Core courses appear remarkably similar across most MBA programs (Segev et al. 1999) and sometimes offer warped and perhaps backwards priorities. Stuart Hart of the University of Vermont comments, 'It is pure and simply the case of the tail wagging the dog. What do I mean by that? That the [...] core in the US model MBA program is like a religion. [It has] become this sort of sacrosanct quasi-religious experience, where the students come into the program and they basically get brainwashed. They become convinced that ... [you learn] the really important stuff when it comes to business in the core. It's about core finance, and core marketing, [plus accounting, economics, operations, information systems, statistics]. ...I think that is exactly backwards.'

Given the entrenched nature of the MBA core and the difficulties that many schools seem to have experienced in trying to change the core or the nature of MBA education, it seems more realistic to acknowledge that the MBA is here to stay. At the same time, there is clear and growing need for something beyond the MBA.

In their book Business Schools Under Fire: Humanistic Management Education as the Way Forward, editors Amann et al. (2011) set out several goals of a humanistic approach to management education. First is educating for citizenship within the business context. Second is questioning the purpose and goals of businesses, so that profits can be understood as not the end but as a means towards some other, presumably higher end, which the editors define as the public good, and what the definition of wisdom offered above (and repeated below) suggests is the greater good - 'the creation of wellbeing for all citizens' (Amann et al. 2011, p. 6).

Further, in the actual world that leaders face, climate change, terrorism that impacts businesses, conflict, inequality (e.g., Piketty 2014), and numerous other human-created problems increasingly demand new forms of leading and managing, imbued with values that go beyond profit maximization to encompass more humanistic and ecological concerns are only some of the issues facing them. Such issues demand significant change, what McIntosh (2013) called a necessary transition. And change means dealing with people, societal and ecological issues, and big picture thinking. Rather than formulaic and purely analytical responses, such leaders need to take into account the changed context in which today's organizations operate and move their enterprises in new directions. Ackoff (1999) once defined wisdom as the 'ability to see or think through the consequences of one's decisions.' Those consequences include human and ecological impacts, the ways in which decisions and actions affect a wide range of stakeholders, and the long-term implications for the business of today's decisions. None of these things are readily found in formulas, problem-solving, and narrowly construed functional expertise. Instead, they require the attributes of wisdom as defined above: moral imagination, systems understand, and aesthetic sensibility — in the service of a better world. 
Further, technological innovations are shifting our very understanding of what organizations, even corporations, are and how they are likely to be designed in the future, (Davis 2010, 2013), not to mention how capitalism itself is going to evolve. The future may well hold very different organizational forms and expectations of business, most likely networked forms, than those on which 20th century management theory is currently based (Davis 2013; Rifkin 2014). As Davis (2010, 2013) contends, future corporations are likely to be more temporary and less stable, employ fewer and more highly-skilled people, be more networked and decentralized in their decision making than they have been in the past. Movements toward what Rifkin (2014) terms the sharing economy and towards localization of production (also Schor 2010), combine with what Davis (2010) terms the 'twilight' of the corporation as it is typically understood. All of these and many other factors contribute to a context in which humanistic leadership education - education that aims for developing wisdomis sorely needed.

\section{Beyond the MBA for Leading and Managing}

Since the MBA degree is unlikely to go away, there may be other ways to ensure that business schools develop leadership programs premised on humanistic values that broaden the scope and purpose of leaders and the enterprises that they lead. In doing do, business schools generally could simply acknowledge that the MBA is a technically, functionally, and analytically-oriented degree best suited for the purpose of educating early-career business people taking their first few positions, which tend to be analytically, technically, and functionally oriented.

Leader development for wisdom in a humanistic model, however, is a quite a different animal than the MBA and demands a different approach. That approach might involve new models of lifelong learning, in which learners - people in leading and managing positions or about to assume those positions - come to programs sporadically and developmentally throughout their careers to get some sort of new degree. Such programs could engage active and workbased learning strategies (Raelin 1999) in formats the bring leaders together periodically to address a variety of subject matters, then send them back to their enterprises where they can put what they learned into practice and then reflect, both individually and in groups, on what they learned. Different formats could be devised, with different content, depending on the institution and the leaders' needs and interests (for examples of how such programs might work, see Waddock and Lozano 2013). The core, however, should be focused on developing wisdom as defined above.

While recognizing that leading is not something to be 'mastered,' but rather is a lifelong learning process, we can (recognizing how universities actually operate and the kinds of degrees they offer) call is something like the MLM - master of leading and managing. It could have a timeline associated with it, but not, for example, be obtained in under a certain number of years and without a certain number of contact hours and coursework. Coursework of both a broadening and practical nature, say meeting for several days a few times a year over a period of, e.g., one to-ten years could be invented. Such designs, which would presumably be uniquely developed by each business school, would recognize that learning to lead is a long term process rather than a 'once and done' approach and that it requires both hands-on practice and reflection (Raelin 1999; Schön 1983; Argyris and Schön 1974). 
Some alternatives that focus on leadership development do exist. One of these alternatives is the International Masters in Practicing Management Program, which Henry Mintzberg helped to create (see http://www.impm.org/ for details) This program focuses on critical reflection and developing mindsets as part of leadership development, sets modules in five countries, is geared at managers from a wide range of international organizations, and is oriented to enabling managers in practice to learn from their own experiences, and share their insights with each other. Mintzberg states, 'I'd say undergraduate programs should teach people to think and should be rooted largely in the disciplines like economics, mathematics, psychology, sociology. MBA programs should be far fewer and devoted exclusively to training people for analytical jobs like marketing research. Then we need lots of programs for practicing managers' (for more of Mintzberg's ideas on management education, see Mintzberg 2004).

Similarly, once future leaders have learned some of what the University of Vermont's Stuart Hart calls 'basic blocking and tackling skills,' i.e., knowledge of what are now called the functional areas of management, basically the MBA core, and they move to leadership positions, they need different skills and capabilities. 'The real program,' Hart explains, needs to be future-oriented, 'focused on sustainable enterprise, clean tech innovation, getting on the ground, how you embed businesses out there in the communities. How do you create an embedded form of innovation? How do you design these new ventures? How do you get them financed? How do you get them up and running? How do you scale them? ... The objective [should be] for the people ...to actually launch new initiatives.' In other words, better learning will likely occur when students are deeply engaged in creating and leading enterprises that actually matter to them, or other work that has a potential to make a difference in the world. That is when the humanistic values associated with the multiple bottom lines of social enterprise come into play (i.e., ESG - environmental, social, and governance or triple bottom line - people, planet, and profits), and it also a time when the impact of leading becomes more pronounced. Recognizing that, in a very real sense, every business is social and every business affects the natural environment, is a core element of humanistic leadership.

Michigan's Andy Hoffman highlights this perspective and concludes, '[Future leaders...] are still being taught that your responsibility is only to yourself, that your only obligation is to make yourself rich and somehow we'll all benefit from it. I think that's a myth just like trickledown economics is a myth. ... I would like to see more of a notion of a calling or a vocation in management education. ... We have to come to grips that there's something sacred, important, and powerful in becoming a manager [or leader]. ...In Canada when you graduate from an engineering program you get a ring [that] is supposedly made from the steel from a bridge that failed. People were killed, and it was embarrassment, a source of shame to the engineering profession. There is a whole ceremony where you get the ring from an engineer already in the profession. The symbolism and the ritual connect you to others in the profession. You take a sacred oath, like a Hippocratic Oath, that you will serve society. Somehow we have to bring this kind of obligation and purpose into management and management education.'

\section{A Wisdom-Based Approach to Leadership Education}

A wisdom-based approach to leadership development inherently recognizes the sacred trust that Hoffman speaks of above. The idea of wisdom as moral imagination, systems understanding, and aesthetic sensibility in the service of the greater good is key to developing humanistic leaders. 


\section{Moral Imagination}

Pirson and Amann (2010) argue that there are three elements of humanistic management that need to be incorporated into management education: unconditional respect for human dignity of everyone, ethical reflection integrated into business decision-making, and normative legitimacy for company actions and decisions. These three components are integral to what Werhane $(1999,2002,2008)$ calls moral imagination in that they foster the ability to see the ethical consequences and implications in organizational, interpersonal, and societal context, which is the essence of moral imagination.

Humanistic leadership education emphasizes so-called softer subjects of human behavior, ethics, culture, business in society, responsibility, sustainability, and stakeholder relationships (among others) as crucial supplements to analytical and technical knowledge. Leading is not simply about the numbers or the analysis, no matter how powerful those numbers or analysis might be. As an example, Robert E. (Bob) Quinn, University of Michigan, comments that vast numbers of business school graduates have little sensitivity to changing the human culture of organizations, as one example of this gap.

Quinn relates a story to make his point. He received a phone call from an information technology head, who was about to launch a major change project for his company. Several people had told the technology manager to contact Quinn to learn something about changing organization culture. The eight team members who were to lead the change objected, saying it would be a waste of time. Quinn reflects, 'So here is a highly-trained, competent, well-intentioned professional about to change the company, but he doesn't know what culture is. He doesn't know about people. Now, that's the equivalent of training a medical doctor to operate on the brain, while making certain all through his education he's never learned that the body has a heart in it, or arteries, or feet. It's unthinkable... Well, that story is not an unusual story. That is the dominant story. That is the norm.' Such a manager lacks moral imagination because he or she cannot even begin to imagine the human elements in organizational change, never mind the ethical aspects.

Well-known stakeholder theorist R. Edward (Ed) Freeman, University of Virginia, argues that because managing and organizing are human activities, they deeply and inextricably embedded with values and moral issues. These human activities invariably take place in a broader context of society and nature, hence are integrally associated with ethical considerations. In essence, the human activities of leading demand moral imagination. Freeman comments that business schools currently, 'Fundamentally ... get business wrong.' He continues on a more humanistic and pragmatic note, '[Business is] how we create meaning for each other. It's how we spend a third to half our lives.' Freeman believes we need to see business 'as a human activity, full of emotion and rationality and spirituality and sexuality and connection with others,' and 'how we create value and trade with each other.' This perspective contrasts with the analytic, narrow economic- and finance-driven lenses, and dichotomized perspectives too frequently in use today, which are essentially bankrupt.

Ensuring that values are central and exposed through what Ed Freeman following Michael Walzer (1994), describes as 'thick moral concepts' would help to strengthen, and humanize, many of today's management disciplines, and is particularly relevant for leadership and managerial development. Freeman states, 'I'd broaden the background disciplines to include more of the humanities and more of the creative arts. [Then] I would take the disciplines of business that exist and I'd deepen them to understand what Michael Walzer would call thick 
moral concepts. A thin moral concept is a concept like, "Don't kill innocent strangers. Don't kill innocent people." A thick moral concept is something like, "Think about your obligation to your children." That is right there in front of you. It has nuance, it has history; it has particularity. How I deal with my children, how you deal with yours, might be different. So Walzer argues that morality starts with the thick and moves to the thin. In business what we've done is supply thin philosophical theories to the disciplines. We need to start with thick concepts. For example, suppose we came to see a marketplace as a place where human beings met to create value and trade with each other? ... Suppose we saw marketing a brand as a promise? We saw a customer as a person? ... What we would do is thicken the disciplines.'

Humanizing the system, integrating ethics and responsibility as part of the whole not separate, and bringing the humanities in leadership education are crucial to future leaders. But ESADE Business School's Josep Lozano recognizes an important caveat in doing so. Lozano calls for integrated human beings as leaders but states, 'It will be really a mistake if you think that this human dimension is so important that we can forget the professional dimension... So the real focus is that we need to not just facilitate good technically trained training professionals, but integrated human beings. ...We need to fight against the schizophrenia that sometimes we create, as business school faculties, schizophrenia in the sense that professional life is one way and personal life is another.'

Moral imagination, then, means explicitly opening up values inherent in leaders' decision making. The University of Denver's Bob Giacalone concurs, and elaborates, 'I think we also have to introduce for lack of a better word the "soul" of things inside education, management education. What do you stand for? That's the question. What will you stand for? Decisions aren't made in the absence of values. ... Our job is to teach students to critically evaluate the decisions that they've got to make within the value set that they have. ... [So what] we need to do is teach students how to critically evaluate their decision making strategies within a values context.'

Further, a humanistic leadership development approach can help close what we can call a contextual gap that adds to a lack of moral imagination. This contextual gap arises when business is presented without sufficient historical, social, or ecological context, and results in a lack of understanding of the moral, historical, and social underpinnings of businesses. Effectively, says Freeman, if leadership education is to develop moral imagination in its students, we need to 're-people' management theory, and in doing so infuse it with the moral values that actually underpin it. Doing so would help avoid what he has called the 'separation fallacy,' in which ethics and theory, action, or decisions are problematically separated. Such a move means seeing markets as places, according to Freeman, 'where human beings meet to create value and trade with each other,' 'where a brand is a promise, a customer is a person, and where what our views of human nature really can be deeply examined and explored.' It would also mean an end to an approach to management that Freeman labels 'the physics of money' and others call 'physics envy,' whereby leading businesses is framed around economics, which is in turn believed to be a hard science akin to physics rather than the very human, relationship-based, activity that it fundamentally is from a humanistic perspective.

A more humane management education that puts people before money, thereby fostering moral imagination, is something that the University of Denver's Robert Giacalone, explicitly emphasizes, saying, 'I think what should be integrated for lack of a better term is a humanitarian ethics in business schools and management education. What we need to do is teach the primacy of people rather than the primacy of money. If we can teach the primacy of people, then our students begin to view the world differently and that's our job. It is our job to teach 
them that people are important.' In other words, by putting people first, rather than profits, management educators would be emphasizing the moral, value-laden aspects of management and fostering greater moral imagination in their students.

One approach to incorporating values within more technical areas, as well as more systemically around leadership issues, is being developed by the Conscious Capitalism movement, headed by Raj Sisodia of Babson College. Conscious Capitalism articulates four systemic core principles or tenets: higher purpose, conscious leadership, a stakeholder orientation, and conscious culture. Sisodia acknowledges that deliberately incorporating principles and values into disciplines goes against the grain for some faculty, who wish to claim that their ideas are value neutral (despite the over valuing of money, profits, and shareholder wealth above all else). Implicitly focusing on more humanistic approaches, he says, '...I would just simply take these four tenets and make them central core elements. Then I would have conscious finance, conscious marketing, conscious people management, conscious strategy, conscious production or operations. In every case, that word means something different in terms of how you would do things.' Consciousness in this context means raising awareness, particularly awareness of the implications and consequences of decisions and actions, which is central to developing moral imagination and, ultimately wisdom. The second aspect of wisdom relevant to humanistic management education is systems understanding.

\section{Systems Understanding}

Systems understanding means having a reasonably comprehensive and realistic assessment of the system of interest, whether it is a team, organization, community, or whole society (Waddock 2010, 2014). Of course, it is impossible for anyone to know and understand everything about a complex adaptive system, which is what all human and ecological systems inherently are (see Waddock et al. 2015). Still systems thinking is a crucially important skill for leading in today's complex world (50+20 2012), and for a future where discontinuous change, complexity of interacting issues and problems, and dealing with global issues like climate change, sustainability, and inequality will become the norm. Thinking about the system as a whole, rather than in its elements or fragments, allows for consideration of the dynamics, interactions, and interconnections that exist among the elements of the system. It permits understanding that when a decision is taken in one area, it will produce long term and ultimately not knowable effects in other parts of the system. By understanding the system as a whole, rather than just its functional or technical aspects, leaders can make wiser decisions for the whole enterprise - and for the contexts in which that enterprise is embedded.

Context matters, after all. While it is unlikely that disciplines will fully disappear from even a leadership and managerially-oriented curriculum, they are frequently taught as if they could be separated from the other functions and values of enterprises, that is, as if they operate independently of other disciplines. Bob Giacalone notes that while it is important for business students to learn about the functional areas of management, e.g., finance, accounting, marketing, operations, and human resource management, future leaders need to understand those functions, as he puts it, 'within the context of living,' and 'with a moral underpinning.'

Speaking systemically, and encompassing moral imagination as well, Giacalone states, 'You have to have a higher aspiration. For example, the aspiration of a good lawyer is not win cases; it's to bring about justice. The aspiration of a doctor is not to solve this particular symptom, it's to make the patient well in a broader sense and to keep society at large right.' 
When we begin to think this way, Giacalone notes, 'We begin to see that very clearly and so the aspiration of business has to be something beyond the bottom line.' Otherwise, he argues, 'If you put out people who do not understand that they have a responsibility to a bigger picture, to a greater whole beyond the bottom line, beyond the stockholders, you are in fact putting out a bunch of sociopaths. ... When you do that as a business school, you are complicit in the damage that's being created.'

This holistic perspective speaks to both a higher purpose for leading enterprises in society, and a recognition that everything is, as physicists tell us, connected to everything else (e.g., Capra 1995). Reflecting on a conversation with the Dalai Lama, David Cooperrider of Case Western Reserve elaborates, '[the Dalai Lama] went into this tremendous discourse and conversation around the need for a radical re-orientation from our preoccupation with the self to our concern for the other, and for a few that recognize this fundamental human relatedness, this fundamental interdependence of all of life. I came away from that realizing that that's what our management schools need to be about in a leadership sense. ... We need to reawaken that fundamental intimacy with the whole, that it's irreducible, that it's the foundational starting point. When [consider] the intimacy with the whole, think about how even the language is different, that is, responsibility for the whole. It invites a different kind of conscious relationship when you see that fundamental intimacy or interdependence with the whole.'

Paul Shrivastava, currently Executive Director of Future Earth and formerly of Concordia University, explains the need for systems understanding as well as historical context, 'The first thing is that our management education is not geared to solving the problems of the twenty-first century. It draws its lessons from the disciplines. Disciplines, by definition, are a collection of dogmas of past. So if you're going to learn from the past, they are valuable sources of learning. But they do not necessarily prepare you for the reality that we are going through a period of discontinuity. So the first thing we need to do is to somehow find a way of having a clear view as to what the future needs. In my sense of that view, it has to be sustainable ecologically; it has to be equitable socially; it has to be spiritually and morally engaging and compelling. Those elements are lacking from current educational content. ... We might be actually contributing to the demise of the world if we don't change this old way of looking at things' (for elaboration, see, Muff et al. 2013).

Globalization also poses significant issues for the predominantly Western, even US-centric, model of management education now current. Ways of leading and managing, types of enterprises, relationships among stakeholders, the public policy, accounting, and transparency systems, levels of corruption, and work ethic, among numerous other factors, differ greatly depending on the country or region of the world where an enterprise is headquartered - or has operations. What is considered acceptable in managing and leading in those contexts differs dramatically, yet other than the occasional international management course or case within a given course, little real attention is given to these differences. As Shrivastava argues management education as taught in North America, 'is quite irrelevant to what is going on in India and China. They need a ... a different kind of education.'

Thus, humanistic leaders need to be more human, globally-diverse, future-focused, and sustainability rather than business-as-usual oriented. Tima Bansal, of the Ivey Business School of Western University, believes that with the right approach, people in leadership programs will find solutions to the many problems of the world. She says, 'I think that what we need to do is to not to tell people this is how things are being done, but to provide them with the skill set to know how to process information and understand the world around them. I think that if 
we improve their ability to expand their radar, so to speak, and we stimulate their curiosity, a lot of these problems will be solved. So it's not about finding the right answer. It's about embracing the diversity of answers that will stimulate imagination.'

Systems understanding suggests that much of current management education is rooted in what used to work in the past and assumes organizations that look like they used to look or look today will continue business as usual. With a troubled future facing business and the planet as a whole, and the issues briefly noted earlier, a more humanistic approach can help future leaders understand - and deal with - changes that are likely to prove necessary. Humanistic leaders need not only to be grounded in an historical sense of the development and emergence of businesses and other enterprises over time that connects them with the past — but also in ways of looking at how the future is likely to emerge (see Scharmer 2009, 2013). David Cooperrider, founder of Appreciative Inquiry, states, 'One thing that I would do in our management schools is bring more of that kind of appreciative inquiry where students are searching across cultures for the most powerful images in the present that feed our imagination about the twenty-first century business in society relationship.'

Systems understanding can also be enhanced by interdisciplinary or transdisciplinary courses and educational materials, particularly linked to the humanities and social sciences. Such approaches could result in a broadening of the perspective for leadership students rather than the narrowing that is implicit in much of today's MBA education, which needs to be broadened for humanistic future leaders. For example, areas such as sociology, anthropology, history, literature, and other humanities can place managerial disciplines in their broader social and historical contexts in ways that help learners more broadly think through the issues that they are likely to face as future leaders. MIT's John Van Maanen believes that such integration of humanities would enhance both ethical and systems understanding, indicating, 'Students could choose more electives than they can now, [and avoid the] cookie cutter. ... I don't think you have to label it ethics or morality, but there's a wonderful literature [on business]. Novels, poetry, there's great stuff there that...I think can be very influential.'

Systems understanding, as Werhane $(2002,2008)$ has noted, is integrally linked to moral imagination, in part because as people become more aware and mindful of the whole, it appears that their ethical stance also increases (e.g., Crilly et al. 2008). For example, a principles-or stakeholder-theory based management education would highlight values that go beyond monetary ones and incorporate a more humanistic orientation, while also paying attention to systemic issues and dynamics. Aesthetic sensibility, the next element of wisdom, is also crucially linked to these other two elements, while opening up a new perspective on what it means to be a humanistic leader.

\section{Aesthetic Sensibility}

Humanizing leadership education means taking into account the design and aesthetic elements of a situation, which can be done by enhancing creativity, exploring and improving the ability to interact with other people, and working on other so-called soft skills, not just technical and analytical skills (c.f., Adler 2010). Ian Mitroff, who has pioneered work on crisis management and spirituality in the workplace, among other areas, basically agrees. He notes, 'We need an educated populous more than ever, given the overwhelming problems. ... You have to have a technical education, but you also have to have an education in humanity. Education in humanity is augmented by enhanced imagination and creativity so that management graduates 
can tackle the huge, systemic issues facing the planet and humankind. That contrasts directly what management education now does, according to Tima Bansal. She pointedly states, 'I think what we do at business schools right now is that we squash [curiosity, students' ability to expand their radar, imagination]. We sometimes make them ... into automatons that where firm performance or team performance or just performance generally is the end.'

Disciplines, functions, and the entire operation of any enterprise, or society, are integrally connected and interrelated. That reality argues for a more holistic approach that fosters humanity, creativity, and imagination. Ed Freeman comments that he would love to, 'start something called The Institute for Leadership in the Creative Arts in which we would teach leadership through music, theater, art, literature. We would use the creative arts. That's what management theory is. ...We're trying to start something at Darden [University of Virginia] now called The Institute for Business in Society, in which we broaden the conversation about corporate responsibility to the disciplines of business. ...We need finance professors who understand what responsibility is. We need marketing professors... who take responsibility seriously.'

The ideas above speak to placing management education into its broader societal and ecological contexts, which speaks to the need for 'humanization' within management education that highlights the realities of this context. Josep M. Lozano, Professor at the ESADE Business School in Barcelona, Spain, believes that there is a need for a broad immersion in classic non-business works that have the potential to link management education directly with traditions in the humanities and broader social sciences, 'We need to really create a new understanding about what kind of manager and what kind of organization we need for the future of the world, for the future of our countries. ... I think that we need a vision for business education to reach a stage in which it is more important to read Shakespeare rather than Michael Porter, theories, or management tools.'

The arts are thus an imortant area where humanization of management education might occur, particularly as a resource for engendering passion about an enterprise's or individual's purpose. Such passion is often found in entrepreneurs, but less often in managers of larger enterprises. Paul Shrivastava suggests, 'One of the pathways to [passion], in my view, is the arts. Arts have always been a repository of human passion; we go and see art for the passionate experience, the emotional experience that we get out of it. Unfortunately, over the last 300, 400 years, arts have been reduced to entertainment. But in an evolutionary sense, arts... were a way of expressing our emotional lives. So I'm using arts...to see how through various art based methods, one can reach a different understanding of nature and our role with regard to nature. We use dance and music and drama and theatre and poetry, etc. to reconnect with nature if you will, in an emotionally deep way.'

\section{Purpose: In the Interest of the Greater Good}

To complete our assessment of the potential of teaching for wisdom to inform a more humanistic management education, we need one more element: consideration of the greater good. We can think of this aspect of wisdom as helping to frame a discussion about purposefor leaders, their stakeholders, and their enterprises. One thing that management educators need to do - and have their students do - is more carefully consider the fundamental purpose of business. The questions at the heart of many critiques of business schools go to their very purpose: what are business schools educating people to do? Moving beyond what Hayes and 
Abernathy (1980) called the 'paralysis of analysis' means opening people up to inquiry, to asking the right questions, and their own — and others' - humanity. Doing so would change the nature of decision making because more things would be considered (e.g., than profitability). Questions, for example, about the real purposes of the firm in meeting needs, providing jobs and meaningful work, and otherwise addressing societal expectations need to be deeply developed.

Tomorrow's leadership education arguably needs to be quite different from the industrial model and one-size-fits-all approach of most, but certainly not all, business schools today. Change in organizations, including business schools, has to start from within the individuals who comprise that institution, particularly those individuals responsible for delivering on its purposes. As Gandhi famously said, we have to 'be the change [we] wish to see in the world.' Changing leader education therefore means focusing anew on its purpose, as Raj Sisodia of Babson College, recognizes. Sisodia, also co-founder of the Conscious Capitalism movement, puts it bluntly, 'Well, I would start with the question of purpose. What is the purpose of our institution, first of all? ...What are we trying to do? [Purpose] has to align with society. It has to be not about just serving the needs of business or the students, but ultimately doing something that is positive for the world. Then I would add a lot of richness to what business is about in a historical context, understanding of the role of business in society, and the fact that business creates all this value. How it can do more of that?'

Such approaches stand in distinct contrast to the rather simple, reassuring, and wrong balm that the sole purpose of the firm is to 'maximize shareholder wealth.' Firms necessarily interact with other stakeholders and entities in society and the natural environment, so managing and leading is actually a much more complex endeavor than the mantra of maximizing profits or wealth implies. It is, as interviewees suggested, a deeply human and relational activity that involves business in society and impacts the broader array of stakeholders and other living beings that interact with any enterprise. This perspective is exemplified in the words of Andrew (Andy) Hoffman,. Hoffman comments, 'I agree with Rakesh Khurana [author of the highly acclaimed critique of management education, From Higher Aims to Hired Hands] when he writes that there is something wrong in management education when the critical issues of our day are not discussed, including income inequality, healthcare, environmental degradation, the financial crisis.'

The predominance of money as a goal - both personal and for companies - is quite problematic, since true purpose has little to do with money for most people. Indeed, the same is actually true for companies, which must do something that meets a need for customers if they are to succeed and also inspire employees and other stakeholders to hard work and action - that is, as Freeman stated above, to create meaning for their stakeholders. That happens through purpose, not necessarily monetary incentives (Pink 2011). Bob Giacalone reflects this perspective, saying, 'What we've got [in management], I think, is a profession where money is the driving force. Business schools have a responsibility to balance that out ... and teach their students to understand where they fit into the tapestry of life.'

The consequences of this failure to ask the right questions, focus on the issues of the day, or engage in business as a human activity are serious enough that the University of Michigan's Bob Quinn notes that if MBA education, for example, is to be used predominantly to educate people for their first jobs, which tend to be more analytic than managerial, then something more is needed for people who hold positions of real responsibility where human issues abound and cannot be avoided. Quinn comments, 'I think that we have a responsibility to invent something that does not exist. It's got to be so powerful and so attractive that people 
who hate the notion are attracted to it, because people like that are terrified - so they say "I hate that touchy-feely crap." What that means is "I'm really afraid. I've been going through life, my marriage, my organizational career, leaving behind a trail of human debris, knowing that I'm screwing up, but not knowing how to change it, and I'm terrified." ...We have to transform that fear.' Transforming that fear, however, means going beyond the numbers and in a very real way re-purposing the business school towards a more humanistic endeavor that recognizes the embeddedness of business in societies and in the natural environment and with people, who have inherent dignity and worth (Hicks 2011).

\section{So...What Would Humanistic Leadership Education Look Like?}

The arguments above lead to several conclusions and ways of moving forward towards humanistic leadership development programs, which I will summarize in the bullets below:

- Accept that MBA programs educate analysts and technical/functional specialists for early career-stage positions.

- Focus leadership development on wisdom through developmental leadership programs that bring practicing leaders into connection with each other over relatively long periods of time separated by real-world applications of and reflection on the ideas they are learning.

- View leadership development as a lifelong learning process that happens developmentally over time and devise programs that meet different needs at different stages of development.

- Recognize the complexity and issues in the world leaders face and design programs that incorporate that complexity, the need for change leadership, and expose leaders to stakeholder, business, and socio-ecological issues.

- Place business and leading in their historical and socio-ecological contexts, and teach about how to understand and cope with likely futures.

- Use a wisdom-based approach that enhances moral imagination, systems understanding, and aesthetic sensibility in the service of the greater good to develop leaders who understand the need for basic human dignity, ethical reflection, and normative legitimacy for companies.

- Moral imagination: emphasize the 'soft' subjects including ethics, interpersonal relations, social, cultural, and ecological realities of human enterprise in a context that encourages reflective practice and raising up of ethical, ecological, and values issues. Incorporate humanities and creative arts into leadership thinking and reflection to develop the whole person as leader. Encourage a more 'conscious' or mindful approach to leading, possibly through incorporating mindfulness practices into leader development.

- Systems understanding: build in approaches that foster systemic understanding and consideration of 'wholes' rather than fragments, recognizing complexity, interconnectedness, and interdependence of elements in the whole. Place businesses and other institutions, as well as analysis and functions, into their historical, societal, and ecological contexts. Build in futures and global orientations that help leaders to think forward, not just rely on past experiences and knowledge. Foster creativity and curiosity.

- Aesthetic sensibility: foster creativity, design thinking, holistic thinking, and intersection of leadership issues with aesthetic ones. Teach leadership issues through the arts in a wide variety of ways. 
- Purpose: Focus on individual, enterprise, and social purpose, taking a multiplicity of stakeholders and issues into consideration, asking good questions that require complex answers.

Obviously, this summary merely outlines a conceptual approach to humanistic leader development. It does provide a framework, however, for guiding the development of actual programs, which necessarily will differ in their specifics depending on the institution and its capabilities and the target set of leaders. The goal, after all, as stated by the Humanistic Management network is to clarify the roles of businesses in society and help businesses and their stakeholders 'reap the benefits of free market economies whil[e] becoming more effective in creating shared benefits and prosperity' (http://www.humanetwork.org/index.php/en/aboutus/our-pledge-and-activities). It is a goal worth pursuing.

Author's Note This paper is based on a series of interviews with 28 leading academics undertaken for my book Intellectual Shamans: Management Academics Making a Difference (Cambridge, 2015). The present work is predominantly from parts of interviews not used in the book, and all direct quotes are from those interviews. The author would like to thank the scholars interviewed in this research for their openness and willingness to participate in the research and share their views. I take their ideas about management education beyond the MBA to humanistic leadership development.

Alphabetical Listing of Interviewees Quoted in Text:

Tima Bansal, Canada Research Chair in Sustainability at the Ivey Business School of Western University, London, Ontario

David Cooperrider, Fairmount Minerals Professor of Social Entrepreneurship at Case Western Reserve University and founder of Appreciative Inquiry

R. Edward (Ed) Freeman, University Professor and Elis and Signe Olsson Professor of Business Administration, University of Virginia Darden School of Business

Robert (Bob) Giacalone, Bill Daniels Chair in Business Ethics at the Daniels College of Business, University of Denver

Stuart Hart, Professor Emeritus and S.C. Johnson Chair Emeritus in Sustainable Global Enterprise at Cornell University, and Steven Grossman Endowed Chair in Sustainable Business at the University of Vermont

Andrew C. (Andy) Hoffman, Holcim (US) Professor of Sustainable Enterprise at the University of Michigan, and Director of the Erb Institute for Global Sustainable Enterprise

Josep Maria Lozano, Professor, ESADE Business School, Barcelona, Spain

Ian Mitroff, Professor Emeritus at the Marshall School of Business and Annenberg School for Communication, University of Southern California

Henry Mintzberg, Cleghorn Professor of Management Studies, McGill University

Robert E. (Bob) Quinn, Margaret Elliot Tracy Collegiate Professor in Business Administration, University of Michigan Ross School of Business

Raj Sisodia, F.W. Olin Distinguished Professor of Global Business, Babson College, and co-founder Conscious Capitalism

Paul Shrivastava, Distinguished Professor and Director of the David O'Brien Centre for Sustainable Enterprise, at Concordia University; currently Executive Director of Future Earth

John Van Maanen, Erwin H. Schell Professor of Management, Massachusetts Institute of Technology

\section{References}

50+20. 2012. The 50+20 Agenda: Management Education for the World. Posted at: http://50plus20.org/wpcontent/uploads/2012/06/5020_AGENDA_PRINT_a4_English.pdf, viewed 7/8/14.

Ackoff, Russell L. 1999. On Learning and the Systems that Facilitate It. Reflections, 1 (1): 14-24, reprinted from The Center for Quality of Management, Cambridge.

Adler, N.J. 2010. Going beyond the dehydrated language of management: leadership insight. Journal of Business Strategy 31(4): 90-99. 
Adler, N.J., and A.W. Harzing. 2009. When knowledge wins: transcending the sense and nonsense of academic rankings. Academy of Management Learning \& Education 8(1): 72-95.

Amann, W., Pirson, M., Dierksmeier, C., Von Kimakowitz, E., \& Spitzeck, H. 2011. Business schools under fire: Humanistic management education as the way forward. Palgrave Macmillan.

Argyris, C., and Schön, D.A. 1974. Theory in practice: Increasing professional effectiveness. San Francisco: Jossey-Bass.

Bennis, W.G., and J. O’Toole. 2005. How business schools lost their way. Harvard Business Review 83(5): 96104.

Capra, F. 1995. The Web of Life. New York: Anchor Doubleday.

Cheit, E.F. 1985. Business Schools and Their Critics. California Management Review 27(3): 43-63.

Crilly, D., S.C. Schneider, and M. Zollo. 2008. Psychological antecedents to socially responsible behavior. European Management Review 5(3): 175-190.

Datar, S. M., Garvin, D. A., \& Cullen, P. G. 2010. Rethinking the MBA: Business education at a crossroads. Harvard Business Press.

Davis, G.F. 2010. Twilight of the Berle and Means Corporation. The Seattle UL Rev. 34: 1121.

Davis, G.F. 2013. After the corporation. Politics \& Society 41(2): 283-308.

Ghoshal, S. 2005. Bad management theories are destroying good management practices. Academy of Management Learning \& Education 4(1): 75-91.

Giacalone, R.A. 2004. A transcendent business education for the 21st century. Academy of Management Learning \& Education 3(4): 415-420.

Giacalone, R.A. 2007. Taking a red pill to disempower unethical students: Creating ethical sentinels in business schools. Academy of Management Learning \& Education 6(4): 534-542.

Giacalone, R.A., and K.R. Thompson. 2006. Business ethics and social responsibility education: Shifting the worldview. Academy of Management Learning \& Education 5(3): 266-277.

Hayes, R.H., and W.J. Abernathy. 1980. Managing our way to economic decline. Harvard Business Review 58(4): 66-77.

Hicks, D. 2011. Dignity: The essential role it plays in resolving conflict. New Have: Yale University Press.

Khurana, R. 2010. From higher aims to hired hands: The social transformation of American business schools and the unfulfilled promise of management as a profession. Princeton University Press.

McIntosh, M. (ed.). 2013. The Necessary Transition: The Journey Towards the Sustainable Enterprise Economy. Sheffield: Greenleaf.

Mintzberg, H. 2004. Managers, not MBAs: A hard look at the soft practice of managing and management development. Berrett-Koehler Publishers.

Muff, K., Tyllick, T., Drewell, M., North, J., Shrivastava, P. \& Haertle, J. 2013. Management Education for the World: A Vision for Business Schools Serving People and Planet. Edward Elgar.

Pfeffer, J., and C.T. Fong. 2002. The end of business schools? Less success than meets the eye. Academy of Management Learning \& Education 1(1): 78-95.

Piketty, T. 2014. Capital in the Twenty-First Century. Cambridge: Harvard University Press.

Pink, D.H. 2011. Drive: The surprising truth about what motivates us. New York: Penguin.

Pirson, M., \& Amann, W. 2010. Humanistic Management Education-Concluding Observations and Suggestions. Fordham University Schools of Business Research Paper, (2011-002).

Porter, L.W., and L.E. McKibbin. 1988. Management Education and Development: Drift or Thrust into the 21st Century. New York: McGraw-Hill.

Raelin, J.A. 1999. Work-based learning: The new frontier of management development. Reading, MA: AddisonWesley.

Rifkin, J. 2014. The Zero Marginal Cost Society: The Internet of Things, the Collaborative Commons, and the Eclipse of Capitalism. Palgrave Macmillan.

Scharmer, C.O. 2009. Theory U: Learning from the future as it emerges. San Francisco: Berrett-Koehler Publishers.

Scharmer, O. 2013. Leading from the Emerging Future: From Ego-System to Eco-System Economies. San Francisco: Berrett-Koehler.

Schor, J. 2010. Plenitude: The New Economics of Real Wealth. New York: Penguin.

Schön, D.A. 1983. The reflective practitioner: How professionals think in action (Vol. 5126). New York: Basic books.

Segev, E., Raveh, A., \& Farjoun, M. 1999. Conceptual maps of the leading MBA programs in the United States: Core courses, concentration areas, and the ranking of the school. Strategic Management Journal 20(6): 549565 .

Senge, P. 1990. The fifth discipline: The art and science of the learning organization. New York: Currency Doubleday. 
Shipper, F. 1999. A comparison of managerial skills of middle managers with MBAs, with othermasters' and undergraduate degrees ten years after the Porter and McKibbin report. Journal of Managerial Psychology 14(2): $150-164$.

Waddock, S. 2010. Finding wisdom within-The role of seeing and reflective practice in developing moral imagination, aesthetic sensibility, and systems understanding. Journal of Business Ethics Education 7: 177196.

Waddock, S. 2014. Wisdom and responsible leadership: Aesthetic sensibility, moral imagination, and systems thinking. In Aesthetics and business ethics, Issues in business ethics, Vol. 41, ed. D. Koehn and D. Elm, 129147. Netherlands: Springer.

Waddock, S., and J.M. Lozano. 2013. Developing more holistic management education: lessons learned from two programs. Academy of Management Learning \& Education 12(2): 265-284.

Waddock, S., Dentoni, D., Meszoely, G., \& Waddell, S. 2015. The Complexity of Wicked Problems: Implications for Agents Seeking Collaboration for Large Systems Change. Journal of Organizational Change Management.

Walzer, M. 1994. Thick and Thin. Moral Arguments at Home and Abroad. Notre Dame" University of Notre Dame.

Werhane, P.H. 1999. Moral Imagination and Management Decision Making (The Ruffin Series in Business Ethics). New York: Oxford University Press.

Werhane, P.H. 2002. Moral imagination and systems thinking. Journal of Business Ethics 38: 33-42.

Werhane, P.H. 2008. Mental models, mental models, moral imagination and system thinking in the age of globalization. Journal of Business Ethics 78: 463-474. 